\title{
PENGARUH TEKNIK PENGAPUNGAN HAYATI MELALUI FERMENTASI Rhizopus sp. TERHADAP KANDUNGAN NUTRISI PAKAN IKAN APUNG
}

\section{Influence of Biofloatation Technique through Rhizopus sp. Fermentation on the Nutritional Quality of the Floating Fish Feed}

\author{
Sabrina Ayu Paramadini ${ }^{1}$, Catur Sriherwanto ${ }^{2, \star}$, Nurlaila $^{2}$, Imam Suja' ${ }^{2}{ }^{2}$, Mutiara Ayu Annisa ${ }^{1}$ \\ ${ }^{1}$ Departemen Kimia, FMIPA, Universitas Indonesia, Gedung G Kampus UI Depok, Jawa Barat 16424 \\ ${ }^{2}$ Balai Bioteknologi, BPPT, Gedung 630 Kawasan PUSPIPTEK, Tangerang Selatan, Banten 15314 \\ *Email: catur.sriherwanto@bppt.go.id
}

\begin{abstract}
Solid fermentation using the mold Rhizopus has been used as an alternative method to improve the physical quality of fish feed, namely stability in water and floatability. Although the fermented fish feed produced had been shown previously to have better stability in water and floatability, the effect of the fermentation on the fish feed nutrition has not yet been known. This study aimed to determine the effect of solid fermentation using the mold Rhizopus sp. on the nutrient content of the fermented feed. In addition, the effect of adding tapioca as much as $0,1,2,3$, and $4 \mathrm{~g}$ on the dry weight loss and density of the fermented feed was investigated. The results showed that the fermented feed contained higher levels of ash and protein compared to the feed without fermentation. The addition of tapioca up to $4 \mathrm{~g}$ had no significat effect ( $p>0.01$ ) on the dry weight loss of the fermented feed, but tended to increase its density compared to those without tapioca addition.
\end{abstract}

Keywords: density, fermentation, fish feed, nutrition, Rhizopus

\begin{abstract}
ABSTRAK
Fermentasi padat menggunakan kapang Rhizopus telah digunakan sebagai metode alternatif untuk memperbaiki kualitas fisik pakan ikan, yakni stabilitas dalam air dan daya apung. Meskipun pakan ikan fermentasi yang dihasilkan sebelumnya sudah dibuktikan memiliki stabilitas dalam air dan daya apung yang lebih baik, namun pengaruh fermentasi terhadap nutrisi pakan ikan tersebut belumlah diketahui. Penelitian ini bertujuan mengetahui pengaruh fermentasi padat menggunakan kapang Rhizopus sp. terhadap kandungan nutrisi pakan fermentasi, dan pengaruh penambahan tapioka sebanyak $0,1,2,3$, dan 4 g terhadap kehilangan berat kering dan mass jenis pakan hasil fermentasi. Hasilnya menunjukkan bahwa pakan fermentasi mengandung kadar abu dan protein lebih tinggi dibandingkan pakan tanpa difermentasi. Penambahan tapioka hingga $4 \mathrm{~g}$ tidak berpengaruh nyata $(p>0,01)$ pada kehilangan berat kering pakan fermentasi, namun cenderung meningkatkan massa jenisnya dibandingkan tanpa penambahan tapioka.
\end{abstract}

Kata kunci: fermentasi, massa jenis, nutrisi, pakan ikan, Rhizopus 


\section{PENDAHULUAN}

Kapang Rhizopus termasuk diantara mikroorganisme yang banyak digunakan dalam pengolahan pangan maupun pakan. Fermentasi menggunakan Rhizopus diketahui meningkatkan nilai nutrisi bahan pangan (Huang et al. 2019) dan pakan (Endrawati and Kusumaningtyas 2017). Biomassa Rhizopus juga memiliki kandungan protein hingga $50 \%$ sehingga berpotensi sebagai sumber protein alternatif untuk pangan (Lennartsson et al. 2018) maupun pakan (Santos et al. 2016; Souza Filho et al. 2017; Asadollahzadeh et al. 2018; Souza Filho et al. 2018). Sebagai sumber protein alternatif untuk pakan ikan, Rhizopus telah diteliti potensinya (Karimi et al. 2018). Ujicoba Rhizopus sebagai komponen pakan sudah dilakukan pada ikan charr kutub (Salvelinus alpinus) untuk mengetahui tingkat kecernaan (Langeland et al. 2016) dan pertumbuhan (Vidakovic et al. 2016) pada ikan tersebut. Selain sebagai nutrisi pakan ikan, penelitian tentang inovasi pemanfaatan Rhizopus kini telah merambah pula pada peningkatan kualitas fisik pakan ikan. Fermentasi padat menggunakan Rhizopus pada pakan ikan tenggelam menghasilkan pakan fermentasi yang memiliki stabilitas di dalam air yang lebih baik sehingga tidak mudah hancur, dan massa jenis yang lebih ringan daripada air sehingga dapat mengapung (Leiskayanti et al. 2017; Zaman et al. 2018; Suliswati et al. 2018).

Peningkatan stabilitas dalam air dan pemunculan sifat apung pakan ikan pada skala industri dilakukan menggunakan mesin ekstruder. Mesin ini memiliki prinsip kerja ekstrusi, yakni penggunaan suhu tinggi dalam waktu pemrosesan yang singkat. Ekstrusi ini merupakan salah satu teknik pembuatan pakan ikan yang memiliki manfaat di antaranya meningkatkan kecernaan, stabilitas atau kekompakan dalam air, serta kemampuan mengapung (Delgado and Reyes-Jaquez 2018). Proses pemanasan selama ekstrusi ini juga mengurangi zat-zat antinutrisi, seperti lektin dan inhibitor tripsin, yang terkandung dalam bahan pakan berupa hasil samping agroindustri (Delgado and Reyes-Jaquez 2018).

Stabilitas dalam air, atau tingkat keutuhan dan kekompakan dalam air, yang dapat ditingkatkan dengan metode ekstrusi, termasuk salah satu kualitas terpenting pakan ikan. Pakan dengan stabilitas dalam air yang baik akan mampu mencegah zat-zat dalam pakan untuk larut selama berada dalam air. Sebaliknya, stabilitas dalam air yang tidak baik menjadikan pakan mudah larut, menyerap air dan mengembang, serta hancur saat berada dalam air. Hal ini selain mengurangi kandungan nutrisi pakan, juga berdampak tidak baik pada pencemaran lingkungan dan kualitas air (Welker et al. 2018). Buruknya kualitas air selain menurunkan produktifitas ikan, meningkatkan resiko penyakit dan biaya produksi, juga memiliki dampak negatif terhadap kesehatan manusia, pekerja di tempat budidaya ikan, dan konsumen ikan tersebut (Ashour et al. 2018).

Pakan ikan apung lebih disukai pembudidaya ikan. Ini karena pakan yang mengapung akan memudahkan dalam pengamatan saat pemberian pakan sehingga dapat mengatur jumlah pakan yang diberikan. Hal tersebut sangatlah penting dalam mengefisienkan pemberian pakan dan memaksimalkan pertumbuhan ikan. Namun pakan apung ekstrusi memiliki sisi yang kurang menguntungkan bagi pembudidaya ikan dikarenakan harganya yang lebih mahal akibat biaya produksinya yang lebih tinggi (Craig et al. 2017).

Mahalnya harga pakan ikan apung komersial ini mendorong para pembudidaya ikan membuat pakan mandiri. Namun pakan mandiri yang mereka hasilkan tidak dapat mengapung karena tidak dibuat dengan mesin ekstruder yang harganya mahal dan pengoperasiannya rumit. Hal inilah yang mendorong penelitian di bidang teknik pengapungan alternatif pakan yang lebih murah dan mudah, salah satunya melalui fermentasi menggunakan kapang tempe Rhizopus (Leiskayanti et al. 2017; Suliswati et al. 2018). Metode ini sederhana karena mirip dengan teknik yang digunakan pada pembuatan tempe. Selain ramah lingkungan, teknik ini memiliki keunggulan dalam hal penggunaan suhu ruangan, tanpa pasokan energi listrik yang besar, dan tidak memerlukan keterampilan khusus pengoperasian mesin serumit ekstruder. Teknik pengapungan mikologis ini sudah terbukti mampu menjadikan pakan ikan yang sebelumnya tenggelam menjadi mengapung dan memiliki stabilitas air yang lebih baik (Leiskayanti et al. 2017; Suliswati et al. 2018).

Pengapungan melalui teknik fermentasi 
ini terjadi karena massa jenis pakan menurun (Suliswati et al. 2018), yang diduga akibat kehilangan berat kering selama fermentasi (Leiskayanti et al. 2017). Meski mengapung adalah sifat fisik yang menguntungkan, namun kehilangan berat kering adalah hal yang merugikan karena berkurangnya berat produk akhir, sehingga perlu ada upaya meminimalisir kehilangan berat kering yang berlebihan. Selain itu, dalam penelitian tersebut belum diketahui dampak fermentasi Rhizopus terhadap kandungan nutrisi pakan ikan. Penelitian ini bertujuan untuk mengetahui kandungan air, abu, protein, lemak, serat, dan karbohidrat pakan ikan sebelum dan sesudah fermentasi. Penelitian ini juga untuk mengetahui apakah penambahan komponen pati berupa tapioka, sebagai salah satu bahan pakan sumber karbohidrat, dapat mengurangi kehilangan berat kering.

\section{BAHAN DAN METODE}

\section{Tempat dan waktu penelitian}

Penelitian ini dilaksanakan pada 3 Juli 2017 hingga 25 Agustus 2017. Penelitian ini dilakukan di Balai Bioteknologi, Badan Pengkajian dan Penerapan Teknologi, Kota Tangerang Selatan, Banten.

\section{Alat dan bahan}

Alat-alat yang digunakan adalah neraca analitik (Kitchen Scale, SF-400 dan Ohaus, Pioneer, PA214, USA), inkubator (Yamato, IS600, Jepang), erlenmayer vakum (PYREX, Jepang), pompa vakum, pendingin tegak, labu bulat (PYREX, Jepang), statip, alat soxhlet (AS ONE), oven (Memmert, 100-800), gegep besi, desikator, cawan porselin, unit destilasi (Behr) dan tanur listrik (Bicasa).

Bahan-bahan yang digunakan adalah pakan ikan tenggelam komersial (Buana Mas, PT. Balqis Sejahtera, Bandung), inokulum Rhizopus sp. (diperoleh dari pengrajin tempe di Serpong, Tangerang Selatan), $\mathrm{H}_{2} \mathrm{SO}_{4}$, $\mathrm{NaOH}$, etanol, aquades dan heksan.

\section{Fermentasi untuk analisa proksimat}

Dua macam sampel pakan ikan, yakni dengan dan tanpa fermentasi, dibuat menggunakan dua perlakuan yang berbeda. Pakan ikan tenggelam sebanyak $37 \mathrm{~g}$ dimasukkan ke dalam cawan petri, lalu ditambahkan 0,74 g inokulum Rhizopus sp. $\left(3,3 \times 10^{6} \quad c f u / g\right)$ dan $30 \mathrm{~mL}$ air kran. Campuran lalu diaduk hingga semua air meresap ke pakan ikan. Untuk perlakuan dengan fermentasi, sampel disimpan di dalam inkubator $27^{\circ} \mathrm{C}$ selama 48 jam. Untuk perlakuan tanpa fermentasi (kontrol), sampel tidak disimplan dalam inkubator $27^{\circ} \mathrm{C}$, tapi langsung ke tahap selanjutnya yakni pengovenan pada $50^{\circ} \mathrm{C}$ selama 24 jam dengan keadaan tutup cawan terbuka. Sampel yang sudah kering dikeluarkan dan dibiarkan hingga mencapai suhu ruang, lalu ditimbang. Sampel dihancurkan menggunakan blender selama 20 detik dengan kecepatan terendah hingga berbentuk tepung untuk selanjutnya diuji proksimat berdasarkan SNI 01-2891-1992 (BSN 1992) sebagaimana dipaparkan pada sub-bab berikutnya.

\section{Fermentasi untuk analisa berat kering}

Prosedur fermentasi pakan ikan untuk tahap ini sama dengan fermentasi pakan untuk analisa proksimat sebelumnya. Perbedaannya adalah sebelum dilakukan pengadukan substrat, ada perlakuan penambahan tepung tapioka ke dalam cawan dengan variasi sebanyak $0,1,2,3$, dan $4 \mathrm{~g}$. Tepung tapioka ini mengandung gula pereduksi ekuivalen sebanyak 72,64 \pm 10,54\% (hasil tidak dipublikasikan). Sampel untuk setiap perlakukan diambil pada jam ke0 (tanpa fermentasi) dan ke-48 untuk dikeringkan sebagaimana prosedur sebelumnya. Sampel diukur volumenya, dan ditimbang untuk menganalisa berat kering, kehilangan berat kering, serta massa jenisnya sebelum dan sesudah fermentasi.

\section{Kadar air}

Botol timbang kosong diletakkan di dalam oven yang sudah distabilkan 1 jam pada $105^{\circ} \mathrm{C}$, lalu dikeluarkan, dan didinginkan di dalam desikator selama 15 menit. Botol timbang tersebut lalu ditimbang menggunakan neraca analitik dan dicatat massanya. Sampel sebanyak $2 \mathrm{~g}$ dimasukkan ke dalam botol timbang, dioven 3 jam pada $105^{\circ} \mathrm{C}$, lalu didinginkan 30 menit di dalam desikator, ditimbang dan dicatat massanya. Pemanasan dalam oven diulangi selama 1 jam, didinginkan 30 menit dalam desikator, dan ditimbang sampai memperoleh bobot tetap (selisih penimbangan terakhir dan penimbangan sebelumnya $\leq 0,0004 \mathrm{~g}$ ). 
Seluruh penimbangan dicatat hingga 4 angka desimal. Kadar air dihitung menggunakan rumus berikut:

$$
\begin{gathered}
\text { Kadar air }(\%)= \\
\frac{\text { bobot sampel setelah pemanasan }}{\text { bobot sampel awal }}
\end{gathered}
$$

\section{Kadar protein}

Sampel sebanyak $0,3 \mathrm{~g}$ dan setengah tablet selenium dimasukkan ke dalam tabung destruksi, dipanaskan perlahan hingga $400^{\circ} \mathrm{C}$, dan didestruksi sampai didapatkan larutan bening. Destilasi lalu dilakukan pada perangkat Kjeldahl dan ammonium yang diperoleh dilarutkan dalam $25 \mathrm{~mL} \mathrm{H}_{3} \mathrm{BO}_{3} 4 \%$. Titrasi kemudian dilakukan menggunakan larutan $\mathrm{HCl} 0,05 \mathrm{~N}$, dan penggunaan larutan $\mathrm{HCl}$ dicatat untuk penghitungan kandungan nitrogen total dan protein kasar dalam sampel. Kadar protein dihitung menggunakan rumus berikut:

$$
\begin{gathered}
\text { Protein total }(\%)= \\
\frac{\left(V_{S}-V_{b}\right) \times N_{H C l} \times 14,01}{\text { bobot sampel awal }} \times 100 \% \times f \\
V_{s}=\text { Volume } \mathrm{HCl} \text { pada titrasi sampel } \\
V_{b}=\text { Volume } \mathrm{HCl} \text { pada titrasi blanko } \\
N_{H C l}=\text { Normalitas HCl } \\
f \quad=\text { Faktor konversi untuk protein dari pakan }
\end{gathered}
$$

\section{Kadar abu}

Cawan porselin dipanaskan 1 jam di dalam tanur listrik yang sudah dikondisikan stabil pada $550^{\circ} \mathrm{C}$. Setelah itu, cawan porselin didinginkan 30 menit di dalam desikator sampai suhu ruang, ditimbang menggunakan neraca analitik, dan dicatat massanya. Ke dalam cawan porselin ini, $2 \mathrm{~g}$ sampel dimasukan, dipanaskan 3 jam pada $550^{\circ} \mathrm{C}$ hingga berwarna putih, didinginkan 30 menit di dalam desikator, dan ditimbang menggunakan neraca analitik dan dicatat massanya. Pemanasan diulangi selama 1 jam, lalu didinginkan 30 menit dalam desikator, dan cawan porselin yang berisi sampel ditimbang sampai didapat bobot tetap (selisih penimbangan terakhir dan penimbangan sebelumnya $\leq 0,0004 \mathrm{~g}$ ). Kadar abu dihitung menggunakan rumus berikut:

$$
\text { Kadar } a b u(\%)=
$$

$\frac{\text { bobot sampel setelah pemanasan }}{\text { bobot sampel awal }} \times 100 \%$

\section{Kadar lemak}

Sampel sebanyak 2,5 g dimasukan ke dalam selongsong kertas, lalu ditambahkan batu didih. Sampel dikeringkan dalam oven pada suhu $105^{\circ} \mathrm{C}$ selama satu jam, didinginkan di dalam desikator selama 15 menit, lalu ditimbang menggunakan neraca analitik. Sampel dalam selongsong tersebut dimasukan ke dalam soxhlet yang dihubungkan dengan labu bulat, diekstraksi 6 jam menggunakan heksan pada $80^{\circ} \mathrm{C}$. Selanjutnya, ekstrak yang tertampung di labu bulat didestilasi, dikeringkan 1 jam di dalam oven $105^{\circ} \mathrm{C}$, didinginkan 30 menit di dalam desikator, dan ditimbang. Pemanasan diulangi dalam oven dan didinginkan dalam desikator sampai mencapai bobot tetap (selisih penimbangan terakhir dan penimbangan sebelumnya $\leq 0,0004 \mathrm{~g}$ ). Kadar lemak dihitung menggunakan rumus berikut:

$$
\begin{gathered}
\text { Kadar lemak }(\%)= \\
\frac{\text { bobot lemak setelah pemanasan }}{\text { bobot sampel awal }} \times 100 \%
\end{gathered}
$$

\section{Kadar serat kasar}

Sampel yang sudah diekstrak lemaknya dikeringkan 1 jam di dalam oven $105^{\circ} \mathrm{C}$. Sampel dimasukan ke dalam erlenmeyer $500 \mathrm{~mL}$, ditambahkan $50 \mathrm{~mL}$ larutan $\mathrm{H}_{2} \mathrm{SO}_{4} \quad 1,25 \%$. Erlenmeyer tersebut dihubungkan dengan pendingin tegak. Kemudian campuran tersebut dipanaskan menggunakan hotplate selama 30 menit, lalu ditambahkan $50 \mathrm{~mL}$ larutan $\mathrm{NaOH} 3,25 \%$, dan dipanaskan kembali 30 menit. Dalam keadaan panas, sampel disaring menggunakan corong buchner yang berisi kertas saring yang telah diketahui massanya. Endapan dicuci dengan $30 \mathrm{~mL}$ larutan $\mathrm{H}_{2} \mathrm{SO}_{4}$ $1,25 \%$ panas, $50 \mathrm{~mL}$ air aquades panas, dan $20 \mathrm{~mL}$ etanol. Kertas saring dikeringkan 30 menit di dalam oven $105^{\circ} \mathrm{C}$, lalu didinginkan 15 menit di dalam desikator, dan endapan yang diperoleh ditimbang. Pemanasan diulangi dalam oven dan didinginkan dalam desikator sampai mencapai bobot tetap (selisih penimbangan terakhir dan penimbangan sebelumnya $\leq 0,0004 \mathrm{~g}$ ). Persentase kadar serat kasar yang diperoleh dihitung. Jika hasil kadar serat kasar melebihi 
$1 \%$ maka kertas saring beserta isinya perlu diabukan dan ditimbang sampai mencapai bobot tetap. Kadar serat kasar dihitung menggunakan rumus berikut:

$$
\text { Kadar serat }(\%)=
$$

bobot serat setelah pengeringan - bobot abu bobot sampel awal

$$
\times 100 \%
$$

Kadar karbohidrat selain serat

Penentuan karbohidrat non serat adalah dengan cara perhitungan atau disebut juga Carbohydrate by Difference. Kadar karbohidrat selain serat kasar didapatkan dari nilai $100 \%$ dikurangi dengan jumlah semua nilai prosentase kadar abu, kadar lemak, kadar protein, dan kadar serat yang terdapat dalam pakan ikan tersebut. Kadar karbohidrat dihitung menggunakan rumus berikut:
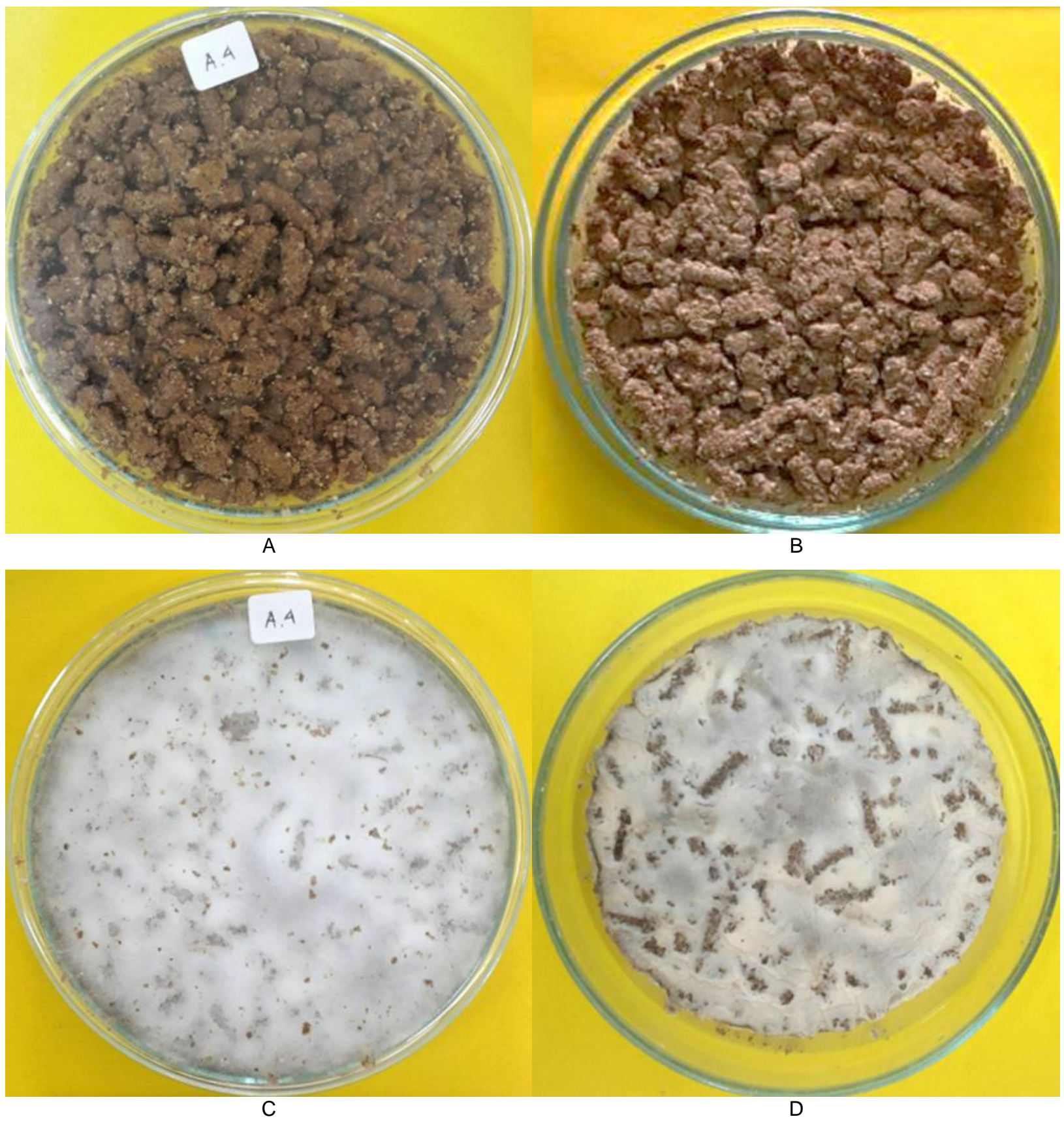

Gambar 1. Fermentasi pakan ikan tenggelam menggunakan Rhizopus sp. dalam cawan petri. Pakan ikan tenggelam yang telah dicampur air dan inokulum pada jam ke-0 sebelum dikeringkan $(A)$ dan sesudah dikeringkan (B). Pakan ikan tenggelam yang telah dicampur air dan inokulum, dan difermentasi pada suhu $27^{\circ} \mathrm{C}$ pada jam ke-48 sebelum dikeringkan (C) dan sesudah dikeringkan (D) 


\section{Kadar karbohidrat $(\%)=$ \\ $100 \%-\%($ protein + lemak $+a b u+a i r)$}

\section{Massa jenis pakan}

Penentuan massa jenis dilakukan terhadap pakan tenggelam komersial maupun pakan apung fermentasi, dengan cara membagi massa atau berat satuan pakan dibagi volumenya. Untuk pakan tenggelam komersial, volume berbentuk tabung mini dan dihitung menggunakan rumus volume tabung, yakni luas alas berupa lingkaran dikalikan tingginya. Pakan fermentasi berbentuk biskuit menyerupai cawan petri, dan volumenya dihitung berdasarkan ketebalan dan diameternya. Penghitungan volume juga dilakukan dengan menggunakan rumus volume tabung.

\section{HASIL DAN PEMBAHASAN}

Setelah 48 jam fermentasi didapatkan hasil yang memiliki tekstur seperti tempe. Substrat yang awalnya berupa butiran-butiran pelet terpisah dan berwarna coklat berubah menjadi satu padatan utuh berwarna putih (Gambar 1). Butiran-butiran pelet merekat satu sama lain oleh jalinan miselium kapang Rhizopus yang padat. Setelah dikeringkan, ada perbedaan berat antara sampel fermentasi dan sampel tanpa fermentasi (Gambar 2). Sampel fermentasi memiliki berat rata-rata $30,20 \pm 3,45 \mathrm{~g}$ per cawan petri, sedangkan sampel tanpa fermentasi 34,82 \pm

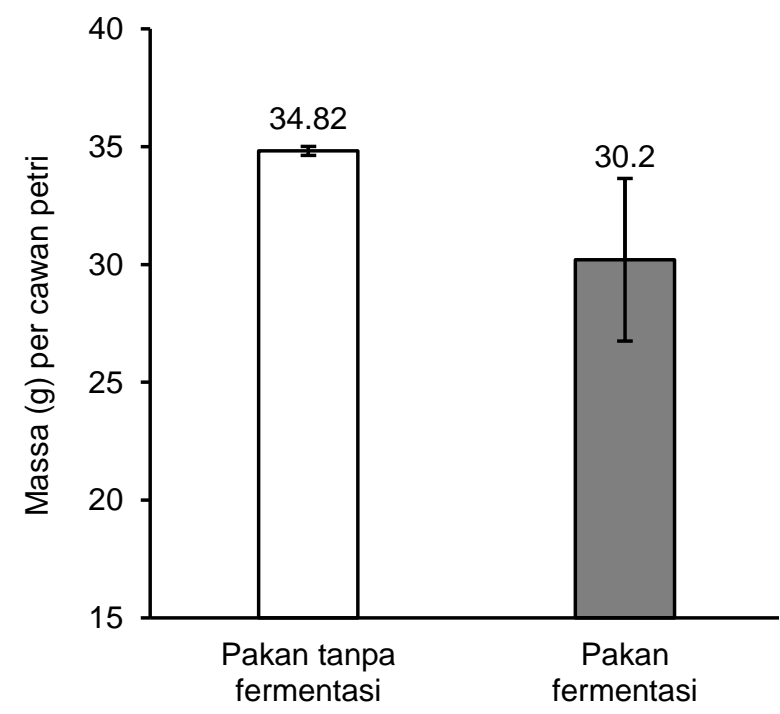

Gambar 2. Berat kering pakan tanpa dan dengan perlakuan fermentasi menggunakan Rhizopus sp. Pakan fermentasi memiliki berat kering lebih ringan
0,19 g per cawan petri. Di sini tampak jelas bahwa ada penyusutan berat kering sebanyak 4,62 $\mathrm{g}$ atau sekitar $13,27 \%$ akibat fermentasi. Ini menunjukkan bahwa fermentasi mengubah sebagian substrat padat menjadi molekul lebih sederhana yang mudah menguap (Christen et al. 2000; Maas et al. 2008; Chukeatirote et al. 2017) saat berlangsungnya fermentasi maupun saat pengeringan. Pakan hasil fermentasi ini dapat mengapung pada permukaan air (Gambar 3).

Hasil analisa proksimat ditampilkan dalam dua grafik batang yang berbeda. Satu grafik didasarkan pada perhitungan yang biasa digunakan dalam menghitung komponen nutrisi (Gambar 4) dan grafik lainnya didasarkan pada berat keseluruhan substrat sebelum fermentasi (Gambar 5). Analisa kandungan nutrisi pakan setelah fermentasi perlu dilakukan untuk memastikan bahwa fermentasi menggunakan Rhizopus menghasilkan pakan fermentasi dengan kandungan nutrisi yang sesuai dengan standard yang telah ditetapkan. Tidak ada perbedaan nyata antara konsentrasi air, lemak, serat, dan karbohidrat non-serat pada pakan fermentasi dan pakan tanpa fermentasi $(p>0,01)$. Namun jika dilihat dari nilai error bar yang didasarkan pada nilai standard deviasinya, kandungan serat cenderung menurun. Kandungan abu dan protein cenderung meningkat setelah fermentasi.

Pakan apung fermentasi mengandung kadar air $4,2 \%$ dan protein $33 \%$. Hal ini sesuai dengan yang disyaratkan SNI untuk

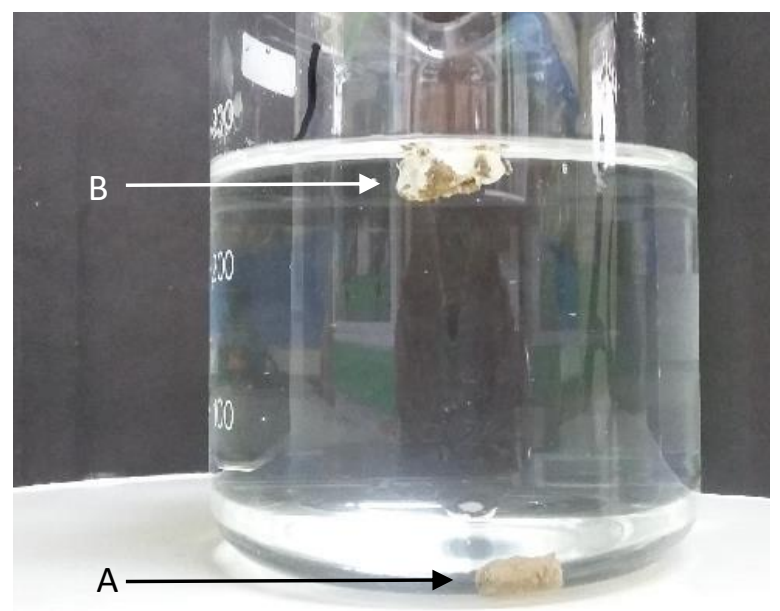

Gambar 3. Pakan ikan tenggelam (A) memiliki kemampuan mengapung (B) setelah difermentasi menggunakan Rhizopus sp. dalam cawan petri 


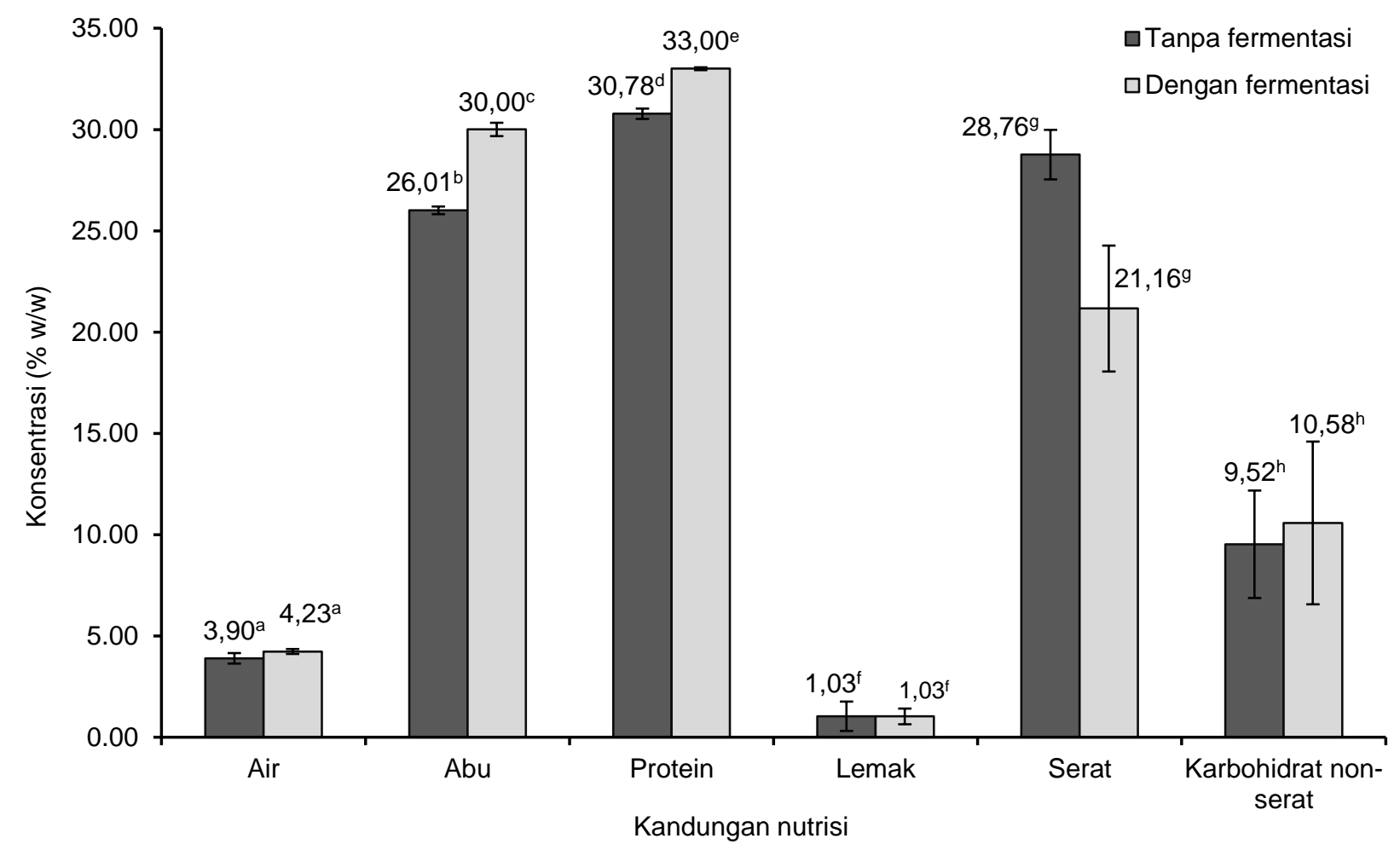

Gambar 4. Hasil uji proksimat pakan ikan tenggelam sebelum dan sesudah difermentasi menggunakan Rhizopus sp. dalam cawan petri pada suhu $27^{\circ} \mathrm{C}$ selama 48 jam. Prosentase kandungan nutrisi pakan fermentasi didasarkan pada berat kering pakan fermentasi tersebut. (Nilai dengan abjad yang berbeda menunjukkan perbedaan yang signifikan pasca uji Tukey's post hoc $(p<0,01))$

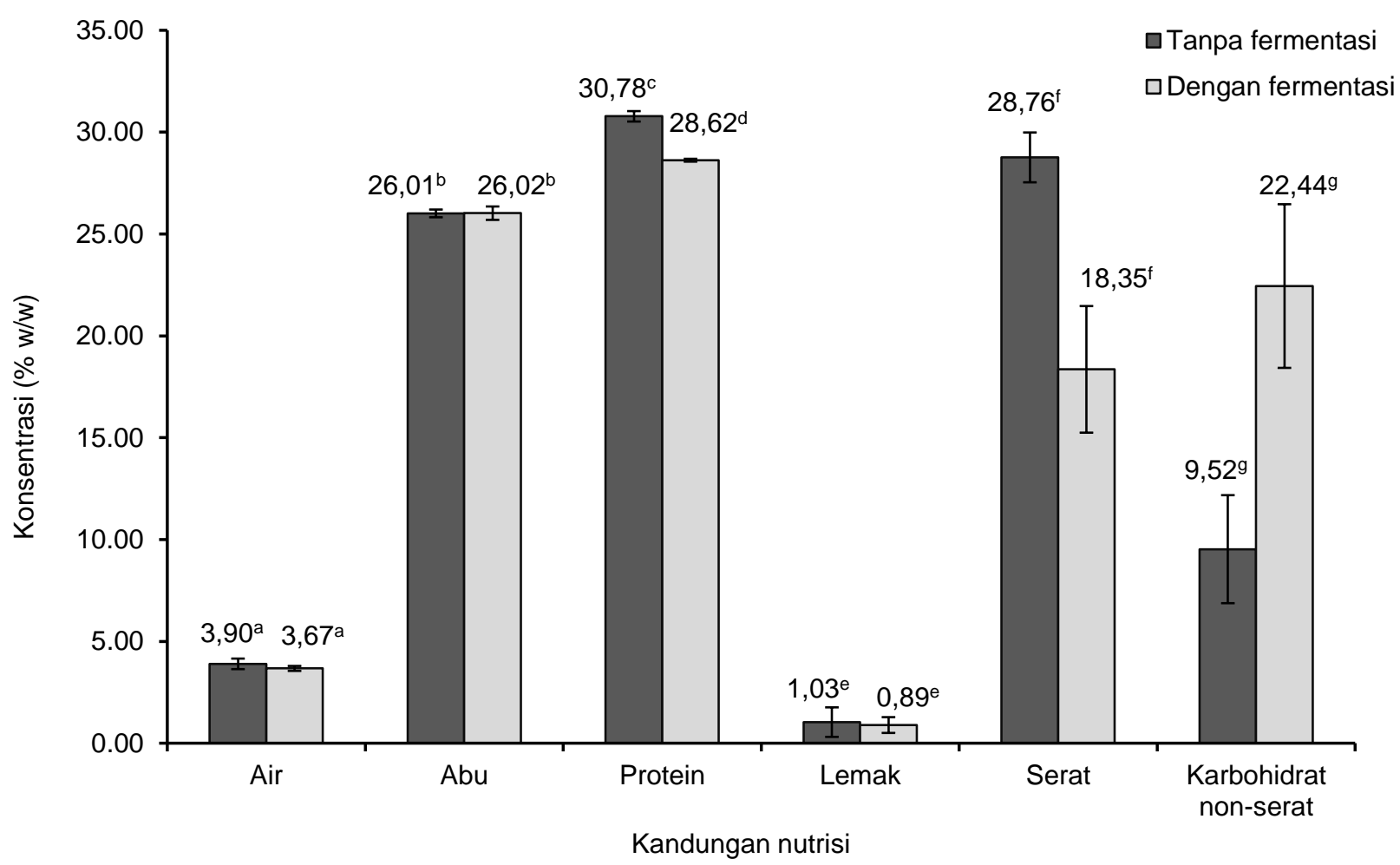

Gambar 5. Hasil uji proksimat pakan ikan tenggelam sebelum dan sesudah difermentasi menggunakan Rhizopus sp. dalam cawan petri pada suhu $27^{\circ} \mathrm{C}$ selama 48 jam. Prosentase kandungan nutrisi pakan fermentasi didasarkan pada berat kering pakan sebelum fermentasi. (Nilai dengan abjad yang berbeda menunjukkan perbedaan yang signifikan pasca uji one-way analysis of variance with Tukey's post hoc ( $p<0,01)$ (Vasavada, 2016)) 
pembesaran ikan patin (BSN 2009a), lele dumbo (BSN 2006a), dan mas (BSN 2006b), serta untuk pembesaran ikan gurami dengan ukuran mulai dari 5 cm (BSN 2009b). Namun kandungan abu dan serat kasar pakan fermentasi melebihi batas maksimal yang ditetapkan SNI untuk pakan buatan tersebut, demikian pula dengan kadar lemak yang berada di bawah standard minimal (BSN 2006b; BSN 2006a; BSN 2009b; BSN 2009a). Kandungan serat yang tinggi dalam pakan ikan dapat mengganggu pemanfaatan nutrisi oleh ikan dan menghambat pertumbuhannya (Yuniati et al. 2018).

Pada penelitian ini, fermentasi meningkatkan kadar abu dan protein masingmasing sebesar $15,3 \%$ dan $7,2 \%$, sedangkan kandungan serat cenderung menurun $26,4 \%$. Hal yang sama juga dialami oleh peneliti sebelumnya yang melakukan fermentasi padat selama 5 hari pada $30^{\circ} \mathrm{C}$ menggunakan Rhizopus oryzae FNCC 6011 pada substrat dedak padi (Sukma et al. 2018). Dedak padi yang didapat dalam penelitian tersebut mengalami kenaikan konsentrasi abu dan protein masing-masing sebesar $18,6 \%$ and $58,5 \%$, serta penurunan kadar serat sebesar $51,2 \%$ (Sukma et al. 2018). Kenaikan kandungan abu dan protein masing-masing sebesar $18,9 \%$ and $112,5 \%$, serta penurunan kandungan serat senilai $8,3 \%$ terjadi pula saat Rhizopus microsporus var. oligosporus digunakan dalam fermentasi pada batang sagu giling (Ab Jalil et al. 2014). Canedo et al. (2016) melaporkan peningkatan kadar abu dan protein pada fermentasi menggunakan Rhizopus oligosporus CCT 4134 pada substrat ampas gandum pabrik bir sebesar masing-masing $29,2 \%$ dan 46,2\%. Berbeda dengan sebelumnya, pada fermentasi ini serat kasar malah meningkat sebesar 114,9\%. Peningkatan protein berturut-turut sebesar $6,3 \%, 21,2 \%$, dan 6,8\% masing-masing terjadi pada substrat bungkil rapa (Lücke et al. 2018), buah lindur (Amin et al. 2019), dan kedelai (Refaat et al. 2019) yang telah difermentasi masing-masing menggunakan kapang Rhizopus microsporus var. oligosporus, Rhizopus sp., and Rhizopus oligosporus. Namun ada yang berbeda dengan hasil penelitian terdahulu, dimana pada ketiga substrat ini fermentasi menurunkan kandungan abu masing-masing sebesar $4,7 \%, 11,5 \%$, dan $10,0 \%$. Dengan sorghum sebagai substrat pada fermentasi menggunakan kapang Rhizopus oryzae MUCL 28168, Londoño-Hernandez et al. (2018) mendapatkan peningkatan protein senilai 23,9\%. Umam et al. (2015) melakukan fermentasi padat menggunakan Rhizopus oryzae pada substrat campuran dedak padi dan ampas kelapa parut dengan perbandingan yang berbeda, yakni $75 \%: 25 \%$, 50\%:50\%, 25\%:75\%, dan 0\%:100\%. Perlakukan berbeda tersebut menghasilkan pakan fermentasi dengan peningkatan kandungan protein dan serat sebesar masing-masing 48,7\% dan $11,6 \% ; 328,1 \%$ dan $-4,5 \% ; 72,8 \%$ dan $-31,0 \%, 45,1 \%$ dan $15,8 \%$ (tanda minus menunjukkan penurunan). Ini berarti pada semua perbandingan substrat, kadar protein mengalami peningkatan, sedangkan kadar serat mengalami kenaikan hanya pada substrat campuran dedak padi dan ampas kelapa parut dengan perbandingan $75 \%: 25 \%$.

Berdasarkan penelitian ini dan berbagai penelitian terdahulu tersebut fermentasi padat menggunakan strain Rhizopus yang berbeda pada beragam substrat terbukti mampu meningkatkan kandungan protein. Ada pun kadar abu dan serat setelah fermentasi, terdapat perbedaan, ada yang meningkat dan ada yang berkurang. Hal ini mungkin disebabkan karena perbedaan kandungan nutrisi substrat sebelum fermentasi, lama fermentasi, suhu fermentasi, komposisi larutan mineral yang digunakan, serta strain Rhizopus yang digunakan.

Dalam fermentasi, kapang Rhizopus memetabolisme substrat dan mengubah sebagiannya menjadi senyawa yang mudah menguap (volatile compound) (Bramorski et al. 1998; Christen et al. 2000; Chukeatirote et al. 2017). Akibatnya, substrat mengalami kehilangan bobot kering (Aprilia et al. 2016; Leiskayanti et al. 2017), dan pakan hasil fermentasi memiliki bobot kering lebih ringan daripada sebelum fermentasi (Leiskayanti et al. 2017).

Lebih kecilnya berat kering pakan fermentasi dibandingkan pakan sebelum fermentasi menjadikan komponen nutrisi, yang sebenarnya tidak mengalami perubahan kadar selama fermentasi, terlihat mengalami kenaikan. Contohnya adalah abu, yang merupakan mineral padat dan tidak 
mudah menguap, dan tidak dimetabolisme oleh kapang Rhizopus menjadi senyawa yang mudah menguap. Rumus matematika penghitungan kadar nutrisi pakan adalah berat nutrisi tersebut dibagi dengan bobot kering pakan, dimana setelah fermentasi sebagian bobot kering tersebut hilang karena diubah menjadi senyawa mudah menguap. Jadi, abu sebenarnya tidak berubah kuantitasnya setelah fermentasi. Akan tetapi, karena setelah fermentasi ini faktor pembaginya lebih ringan dibandingkan sebelum fermentasi, maka secara matematika nilai abu seolah mengalami kenaikan. Demikian halnya dengan komponen nutrisi lain, yang jika pembaginya dikembalikan ke bobot semula (bobot sebelum fermentasi) maka akan didapatkan betapa sebagian nutrisi tersebut sebenarnya tidak berubah atau justru menurun akibat fermentasi.

\section{Penggunaan pembagi berupa berat kering sebelum fermentasi dalam} penghitungan kandungan nutrisi pakan fermentasi ini lebih tepat dilakukan untuk mengetahui kemampuan kapang Rhizopus dalam sintesa atau degradasi (Santos et al. 2016; Pathania et al. 2018) nutrisi tertentu.
Dengan menggunakan pembagi berat kering sebelum fermentasi, diketahui bahwa dalam penelitian ini sebenarnya tidak ada perubahan kadar air, abu dan lemak akibat fermentasi menggunakan Rhizopus, bahkan protein mengalami penurunan, bukan kenaikan. Demikian pula dengan karbohidrat non-serat, yang awalnya terlihat tidak berbeda nyata sebelum dan sesudah fermentasi (Gambar 4), ternyata mengalami kenaikan jika dilihat dari error bar yang didasarkan pada nilai standar deviasinya (Gambar 5). Penurunan kandungan protein ini besar kemungkinan akibat degradasi sebagian protein substrat menjadi senyawa lebih sederhana, yakni amonia (Sparringa and Owens 1999; Muzdalifah et al. 2017), yang mudah menguap. Sebaliknya, peningkatan kadar karbohidrat non-serat ini disertai dengan penurunan kadar serat, yang mengindikasikan adanya aktivitas selulolitik selama fermentasi yang mengubah serat menjadi karbohidrat dengan rantai lebih pendek atau oligosakarida. Aktivitas selulolitik dari genus Rhizopus ini memang sudah dikenal berdasarkan penelitian sebelumnya (Santos et al. 2016; Pathania et al. 2018).

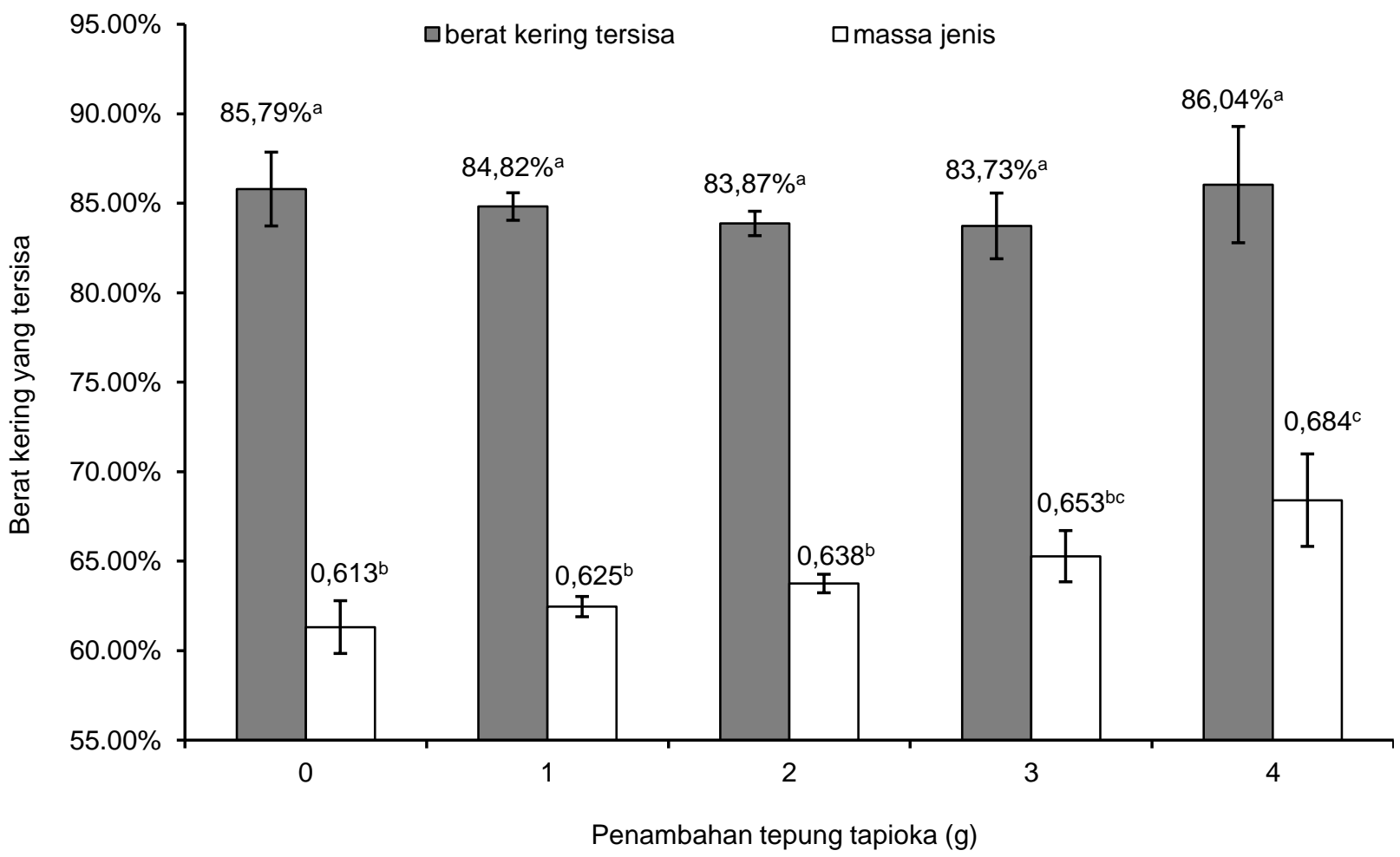

Gambar 6. Pengaruh penanambahan tepung tapioka terhadap berat kering yang tersisa dan massa jenis pakan ikan apung fermentasi. (Nilai dengan abjad yang berbeda menunjukkan perbedaan yang signifikan pasca uj one-way analysis of variance with Tukey's post hoc $(p<0,01)$ (Vasavada, 2016)) 
Mekanisme pengapungan pada pakan ikan apung fermentasi adalah karena menurunnya nilai massa jenis pakan yang awalnya di atas $1 \mathrm{~g} \cdot \mathrm{cm}^{-3}$, menjadi di bawah nilai tersebut. Penurunan massa jenis ini salah satunya diduga karena kehilangan berat kering akibat aktivitas metabolisme kapang Rhizopus yang mengubah sebagian substrat padat, semisal karbohidrat glukosa, menjadi senyawa lebih sederhana yang mudah menguap seperti karbondioksida (Maas et al. 2008). Kehilangan berat kering berlebihan akan berdampak merugikan secara komersial, sehingga diperlukan usaha untuk meminimalisir kehilangan berat ini, salah satunya dengan menaikkan komponen karbohidrat, misalnya dengan menambah tapioka. Dalam penelitian ini, penambahan tepung tapioka hingga 4\% ternyata tidak secara signifikan $(p>0,01)$ mengubah berat kering substrat yang hilang (Gambar 6). Sekitar $14-16 \%$ berat kering hilang akibat fermentasi menggunakan Rhizopus, sehingga berat akhir pakan fermentasi berkisar antara $84-86 \%$ dari berat semula. Hasil ini setara dengan yang diperoleh (Leiskayanti et al. 2017) yang mendapatkan pakan ikan apung fermentasi dengan kehilangan berat kering sekitar 10-14\% setelah fermentasi selama 22-34 jam.

Massa jenis yang didapatkan dalam penelitian ini cenderung meningkat seiring dengan naiknya penambahan tapioka (Gambar 6), namun nilainya di bawah massa jenis air sehingga masih dapat mengapung. Belum dapat dijelaskan secara pasti mengapa hal ini terjadi. Yang jelas, massa jenis pakan ikan apung fermentasi yang berkisar antara 0,6-0,7 g. $\mathrm{cm}^{-3}$ ini lebih tinggi daripada yang dilaporkan sebelumnya oleh Suliswati et al. (2018), yakni 0,33 dan 0,53 $\mathrm{g} \cdot \mathrm{cm}^{-3}$.

\section{KESIMPULAN}

Fermentasi padat pada pakan ikan tenggelam menggunakan kapang Rhizopus sp. pada suhu $27^{\circ} \mathrm{C}$ selama 48 jam menghasilkan pakan ikan apung fermentasi dengan kandungan air, abu, protein, dan lemak yang sama dengan sebelum fermentasi, sedangkan kadar serat menurun, dan kadar karbohidrat non-serat meningkat. Massa jenis pakan fermentasi lebih rendah $\left(<1 \quad \mathrm{~g} \cdot \mathrm{cm}^{-3}\right)$ dibandingkan sebelum difermentasi $\left(>1 \mathrm{~g} \cdot \mathrm{cm}^{-3}\right)$. Penambahan tapioka pada substrat pakan ikan tenggelam tidak berpengaruh pada berat kering yang tersisa setelah fermentasi, tapi menaikkan massa jenisnya dari 0,61 menjadi hingga 0,68 $1 \mathrm{~g} \cdot \mathrm{cm}^{-3}$.

\section{DAFTAR PUSTAKA}

Ab Jalil A, Abdullah N, Alimon AR, Abd-Aziz $S$ (2014) Nutrient enhancement of ground sago (Metroxylon sagu Rottboll) pith by solid state fermentation with Rhizopus oligosporus for poultry feed. J Food Res 4:1-15. doi: 10.5539/jfr.v4n2p1

Amin MNG, Prastiya RA, Hasan MN, Zakariya, Alamsjah MA (2019) Nutrient improvement of Bruguiera gymnorrhiza peel fruit through fermentation using commercial tempeh (Indonesian fermented soybean) mold. IOP Conf Ser Earth Environ Sci 236:012120. doi: 10.1088/1755-1315/236/1/012120

Aprilia D, Widyahapsari N, Indrati R, Setyabudi S (2016) Evaluasi perlakuan pendahuluan menggunakan kalsium hidroksida untuk biokonversi jerami padi menjadi l-asam laktat oleh Rhizopus oryzae AT3. Agritech 36:253-260. doi: 10.22146/agritech.16587

Asadollahzadeh M, Ghasemian A, Saraeian A, Resalati H, Taherzadeh MJ (2018) Production of fungal biomass protein by filamentous fungi cultivation on liquid waste streams from pulping process. BioResources 13:5013-5031. doi: 10.15376/biores.13.3.5013-5031

Ashour M, Abo-Taleb HA, Abou-Mahmoud MM, El-feky MM (2018) Effect of the integration between plankton natural productivity and environmental assessment of irrigation water, ElMahmoudia canal, on aquaculture potential of Oreochromis niloticus. Turkish J Fish Aquat Sci 18:1163-1175. doi: 10.4194/1303-2712-v18_10_03

Bramorski A, Christen P, Ramirez M, Soccol CR, Revah S (1998) Production of volatile compounds by the edible fungus Rhizopus oryzae during solid state cultivation on tropical agro-industrial substrates. Biotechnol Lett 20:359-362. doi: 10.1023/A:1005323229125

BSN (1992) Cara uji makanan dan minuman. Standard Nasional Indonesia (SNI) 01 - 
2891-1992. Badan Standardisasi Nasional (National Standardization Agency of Indonesia), Jakarta, hal 1-35

BSN (2009a) Pakan buatan untuk ikan patin (Pangasius sp.). Standard Nasional Indonesia (SNI) 7548-2009. Badan Standardisasi Nasional (National Standardization Agency of Indonesia), Jakarta, hal 1-6

BSN (2006a) Pakan buatan untuk ikan lele dumbo (Clarias gariepinus) pada budidaya intensif. Standard Nasional Indonesia (SNI) 01-4087-2006. Badan Standardisasi Nasional (National Standardization Agency of Indonesia), Jakarta, hal 1-12

BSN (2006b) Pakan buatan untuk ikan mas (Cyprinus carpio L.) pada budidaya intensif. Standard Nasional Indonesia (SNI) 01-4266-2006. Badan Standardisasi Nasional (National Standardization Agency of Indonesia), Jakarta, hal 1-12

BSN (2009b) Pakan buatan untuk ikan gurami (Osphronemus goramy, Lac.). Standard Nasional Indonesia (SNI) 7473:2009. Badan Standardisasi Nasional (National Standardization Agency of Indonesia), Jakarta, hal 1-5

Canedo MS, de Paula FG, da Silva FA, Vendruscolo $F$ (2016) Protein enrichment of brewery spent grain from Rhizopus oligosporus by solid-state fermentation. Bioprocess Biosyst Eng 39:1105-1113. doi: 10.1007/s00449-016-1587-8

Christen P, Bramorski A, Revah S, Soccol CR (2000) Characterization of volatile compounds produced by Rhizopus strains grown on agro-industrial solid wastes. Bioresour Technol 71:211-215. doi: 10.1016/S0960-8524(99)00084-X

Chukeatirote E, Eungwanichayapant PD, Kanghae A (2017) Determination of volatile components in fermented soybean prepared by a co-culture of Bacillus subtilis and Rhizopus oligosporus. Food Res 1:225-233. doi: 10.26656/fr.2017.6.066

Craig S, Helfrich L, Kuhn D, Schwarz M (2017) Understanding fish nutrition, feeds, and feeding. Virginia Coop Extension, Virginia Tech, Virginia State Univ Publication, Virginia, pp 1-6

Delgado E, Reyes-Jaquez D (2018) Extruded Aquaculture Feed: A Review. In:
Extrusion of Metals, Polymers and Food Products. InTechOpen, London, pp 145163. doi: 10.5772/intechopen.69021

Endrawati D, Kusumaningtyas E (2017) Beberapa fungsi Rhizopus sp. dalam meningkatkan nilai nutrisi bahan pakan. Wartazoa 27:81-88. doi: 10.14334/wartazoa.v27i2.1181

Huang L, Wang C, Zhang Y, Chen X, Huang Z, Xing G, Dong M (2019) Degradation of anti-nutritional factors and reduction of immunoreactivity of tempeh by cofermentation with Rhizopus oligosporus RT-3 and Actinomucor elegans DCY-1. Int J Food Sci Technol. doi: 10.1111/ijfs. 14085

Karimi S, Soofiani NM, Mahboubi A, Taherzadeh MJ (2018) Use of organic wastes and industrial by-products to produce filamentous fungi with potential as aqua-feed ingredients. Sustain 10:119. doi: 10.3390/su10093296

Langeland $M$, Vidakovic A, Vielma J, Lindberg JE, Kiessling A, Lundh T (2016) Digestibility of microbial and mussel meal for Arctic charr (Salvelinus alpinus) and Eurasian perch (Perca fluviatilis). Aquac Nutr 22:485-495. doi: 10.1111/anu.12268

Leiskayanti Y, Sriherwanto C, Suja'i I (2017) Fermentasi menggunakan ragi tempe sebagai cara biologis pengapungan pakan ikan. J Bioteknol Biosains Indones 4:54-63. doi: 10.29122/jbbi.v4i2.2503

Lennartsson PR, Nair RB, Andersson D, Taherzadeh MJ, Souza Filho PF (2018) Vegan-mycoprotein concentrate from pea-processing industry byproduct using edible filamentous fungi. Fungal Biol Biotechnol 5:1-10. doi: 10.1186/s40694018-0050-9

Londoño-Hernandez L, Bolivar G, Ramirez T (2018) Effect of solid state fermentation with Rhizopus oryzae on biochemical and structural characteristics of sorghum (Sorghum bicolor (L.) Moench). Int $\mathrm{J}$ Food Ferment Technol 8:2137. doi: 10.30954/2277-9396.01.2018.4

Lücke $F K$, Fritz V, Tannhäuser $K$, Arya $A$ (2018) Controlled fermentation of rapeseed presscake by Rhizopus, and its effect on some components with relevance to human nutrition. Food Res Int. doi: 10.1016/j.foodres.2018.11.031 
Maas RHW, Springer J, Eggink G, Weusthuis RA (2008) Xylose metabolism in the fungus Rhizopus oryzae: Effect of growth and respiration on I(+)-lactic acid production. J Ind Microbiol Biotechnol 35:569-578. doi: 10.1007/s10295-0080318-9

Muzdalifah D, Athaillah ZA, Nugrahani W, Devi AF (2017) Colour and $\mathrm{pH}$ changes of tempe during extended fermentation. AIP Conf Proc 1803:20036. doi: 10.1063/1.4973163

Pathania S, Sharma N, Handa S (2018) Utilization of horticultural waste (apple pomace) for multiple carbohydrase production from Rhizopus delemar F2 under solid state fermentation. J Genet Eng Biotechnol 16:181-189. doi: 10.1016/j.jgeb.2017.10.013

Refaat AA, Abdel-hady HM, Amin SA, Emam AM (2019) Production and evaluation of soybean tempeh to use as a ready to eat meal in Egyptian hotels. Asian Food Sci J 5:1-9. doi: 10.9734/afsj/2018/43681

Santos TCD, Filho GA, Brito ARD, Pires AJV, Bonomo RCF, Franco M (2016) Production and characterization of cellulolytic enzymes by Aspergillus niger and Rhizopus sp. by solid state fermentation of prickly pear. Rev Caatinga 29:222-233. doi: 10.1590/1983-21252016v29n126rc

Souza Filho PF, Zamani A, Taherzadeh MJ (2018) Edible protein production by filamentous fungi using starch plant wastewater. Waste and Biomass Valorization:1-10. doi: 10.1007/s12649018-0265-2

Souza Filho PF, Zamani A, Taherzadeh MJ (2017) Production of edible fungi from potato protein liquor (PPL) in airlift bioreactor. Fermentation 3:1-12. doi: 10.3390/fermentation3010012

Sparringa RA, Owens JD (1999) Causes of alkalinization in tempe solid substrate fermentation. Enzyme Microb Technol 25:677-681. doi: 10.1016/S01410229(99)00097-6

Sukma A, Jos B, Sumardiono S (2018) Kinetic of biomass growth and protein formation on rice bran fermentation using Rhizopus oryzae. MATEC Web Conf 156:01023. doi: 10.1051/matecconf/201815601023

Suliswati L, Sriherwanto C, Suja'i I (2018) Dampak teknik pengirisan dan pencetakan terhadap daya apung pakan ikan yang difermentasi menggunakan Rhizopus sp. J Bioteknol Biosains Indones 5:127-138. doi: 10.29122/jbbi.v5i2.3096

Umam RD, Sriherwanto C, Yunita E, Suja'i I (2015) Growth of carp (Cyprinus carpio L.) fed with rice bran-coconut bagasse mixed substrate fermented using Rhizopus oryzae. J Bioteknol Biosains Indones 2:81-87. doi: 10.29122/jbbi.v2i2.513

Vidakovic A, Langeland M, Sundh $\mathrm{H}$, Sundell $\mathrm{K}$, Olstorpe M, Vielma J, Kiessling A, Lundh T (2016) Evaluation of growth performance and intestinal barrier function in Arctic Charr (Salvelinus alpinus) fed yeast (Saccharomyces cerevisiae), fungi (Rhizopus oryzae) and blue mussel (Mytilus edulis). Aquac Nutr 22:1348-1360. doi: 10.1111/anu.12344

Welker TL, Overturf K, Snyder S, Liu K, Abernathy J, Frost J, Barrows FT (2018) Effects of feed processing method (extrusion and expansion-compression pelleting) on water quality and growth of rainbow trout in a commercial setting. $\mathrm{J}$ Appl Aquac 30:97-124. doi: 10.1080/10454438.2018.1433095

Vasavada $N$ (2016) One-way ANOVA (ANalysis Of VAriance) with post-hoc Tukey HSD (Honestly Significant Difference) test calculator for comparing multiple treatments. https://astatsa.com/OneWay Anova wit h_TukeyHSD/. Diakses 28 Maret 2019

Yuniati D, Utomo NB, Setiawati M, Alimuddin A (2018) Growth Performance and enzyme activities in catfish [Pangasianodon hypophthalmus] fed with water hyacinth-based diet. Biotropia 25:140-7. doi: 10.11598/btb.2018.25.2.840

Zaman AB, Sriherwanto C, Yunita E, Suja'i I (2018) Karakteristik fisik pakan ikan apung non-ekstrusi yang dibuat melalui fermentasi Rhizopus oryzae. J Bioteknol Biosains Indones 5:27-35. doi: 10.29122/jbbi.v5i1.2793 